ISSN 1392-3196 / e-ISSN 2335-8947

Zemdirbyste-Agriculture, vol. 103, No. 1 (2016), p. 45-52

DOI 10.13080/z-a.2016.103.006

\title{
The variability of the occurrence of Fusarium culmorum in winter wheat grain in relation to climatic conditions and cultivation methods
}

\author{
Ryszard WEBER ${ }^{1}$, Włodzimierz KITA², Wojciech PUSZ ${ }^{2}$, Renata KIELOCH ${ }^{1}$ \\ ${ }^{1}$ Institute of Soil Science and Plant Cultivation, State Research Institute \\ Orzechowa 61, 50-540 Wrocław, Poland \\ E-mail: rweber@iung.pulawy.pl \\ ${ }^{2}$ Wrocław University of Environmental and Life Sciences \\ Plac Grunwaldzki 24A, 50-363 Wrocław, Poland
}

\begin{abstract}
Wheat grains are colonized by a wide range of different saprophytic and pathogenic fungi. Infestation of mycotoxigenic species such as Fusarium spp. raises concerns about the safety of the grains for human and animal consumption. The colonization depends upon various environmental and genetic factors. The aim of the study was to analyse the variability of the incidence of the Fusarium culmorum fungus in wheat grain in relation to years of experiments - environmental conditions, the height of the preceding crop stubble, tillage system and cultivar. The study was conducted in the years 2009-2011, at the Experimental Farm of the Institute of Soil Science and Plant Cultivation in the Lower Silesia Region. The preceding crop was winter wheat. The study included the following experimental factors: factor I - height of preceding crop stubble: a) low stubble, b) high stubble; factor II - soil tillage systems: a) direct sowing, b) ploughless tillage, c) plough tillage; factor III - winter wheat cultivars: a) 'Mewa', b) 'Rapsodia', c) 'Legenda'. Mycological analyses were conducted on the grain from the cultivars harvested at the stage of full maturity. It is noteworthy that in the ploughless tillage system the fungal infestation observed in caryopsis under study was higher than that in the plough tillage system. Within the various tillage systems, the high stubble variant reduced the level of infection of wheat grain with the fungus $F$. culmorum. The wheat cultivars were characterised by varied resistance to grain colonisation by F. culmorum depending on the soil tillage system.
\end{abstract}

Key words: environment, Fusarium culmorum, stubble height, tillage system.

\section{Introduction}

In many regions in Poland as well as in Western Europe, the relative proportion of cereals in the crop structure has already reached a dangerous level of $70 \%$. The common practice of cereal crop rotations or monoculture in the cultivation of winter wheat and rye contribute to the development of fungal diseases. In recent years, fusarium head blight has become a common disease of wheat all over the world (Klix et al., 2008; Xu et al., 2008; Summerell et al., 2010). The high diversity within the Fusarium genus makes it difficult to control fungi on wheat plantations (Infantino et al., 2012). At present, the most frequently recorded species of the fungus in Europe include F. culmorum (W.G.Sm) Sacc., Gibberella zeae (Schwein.) Petch, Gibberella avenacea R.J. Cook, F. poae (Peck.) Wollenw. and Monographella nivalis (Schaffnit) E. Müll. Fungi belonging to the genus Fusarium can produce various mycotoxins, classified as trichothecenes, such as deoxynivalenol (DON), nivalenol (NIV), toxin T-2 and toxin HT-2, as well as other toxins such as zearalenone and fumonisins B1 and B2 (Kammoun et al., 2010; Popovski, Celar, 2013).
Many research reports emphasise the fact that $G$. zeae and F. culmorum are among the most dangerous pathogenic fungi in Europe (Maiorano et al., 2008; Blandino et al., 2010). F. poae, which is becoming more and more widespread in Poland, is less pathogenic than either F. culmorum or G. zeae. Research has shown that $G$. zeae requires higher temperatures to develop than F. culmorum (Häberle et al., 2007). In northern Europe (Scandinavia, Finland and northwestern Russia) and Asia (Siberia and the Russian Far East) the most common Fusarium species responsible for Fusarium head blight (FHB) are the F.avenaceum (currently name G. avenacea)/ arthrosporioides / tricinctum, F. graminearum / culmorum / cerealis and F. poae / sporotrichioides / langsethiae species groups based on morphology (Yli-Mattila, 2010). Studies conducted during the last decade in Holland and Germany indicate an increasing dominance of $G$. zeae in the areas where so far the dominant species has been F. culmorum (Wagacha, Muthomi, 2007; Xu, Nicholson, 2009). The trend may result from the genetic changes in populations of that fungal species (Bateman et al., 2007). 
Airborne ascospores of $G$. zeae may infect cereals faster than the conidia of $F$. culmorum, which rely on rain droplets for dispersal.

The primary factor affecting the rate of infection of the after-crop is the post-harvest residue (Maiorano et al., 2008). Therefore, the preceding crop and the soil tillage system play an important role in controlling the infection of ears of cereals by the fungi of Fusarium and Gibberella genus. In recent years, ploughless tillage has become more and more popular, owing to economic and environmental reasons. The considerable degradation of soil in certain regions of the world, caused by intensive soil tillage, makes it necessary to develop new technologies favouring soil conservation on the one hand, and biodiversity recreating natural biocenoses in areas of intensive agricultural production on the other. Following a previous crop of maize, plough tillage may significantly reduce the occurrence of $F$. culmorum, whereas the application of various forms of ploughless tillage increases the threat of wheat infection by fungi (Blandino et al., 2010). The enhanced biological activity of the upper soil horizons under the conditions of conservation tillage may nonetheless limit the number of pathogenic fungi inoculi (Lenc et al., 2009).

However, the application of various forms of simplified or reduced tillage, and especially of direct sowing, creates additional problems related to an excessive amount of straw remaining on the soil surface. High stubble has significant advantages in the case of direct sowing. Sowing with drills yields good results as long as the straw is laid along the path of the drill and there is no accumulation of post-harvest residue in the sowing groove. Notwithstanding, high stubble increases the risk of infection by fungi, particularly those belonging to the genus Fusarium. This in turn may contribute to a decreased crop yield. Unfortunately, the data concerning the influence of stubble height on the infection of secondary crops by Fusarium fungi remains insufficient.

The aim of the study was to analyse the variability of the occurrence of the F. culmorum fungus in winter wheat grain in relation to environmental conditions years of experiments, height of the previous crop stubble, tillage system and plant cultivars.

\section{Material and methods}

Environment and meteorological conditions. The study was conducted in the years 2009-2011, at the Experimental Farm of the Institute of Soil Science and Plant Cultivation in the Lower Silesia Region (Table 1). The experiment was set up in a split-split-plot design in four replicates, on Stagnic Cutanic Albeluvisol: loamy sand overlying loam. The following crop rotation was employed: spring wheat $\rightarrow$ winter oilseed rape $\rightarrow$ winter wheat (preceding crop) $\rightarrow$ winter wheat (in experiment).

Table 1. Precipitation and mean air temperature during the vegetative period

\begin{tabular}{cccccccc}
\hline Years & March & April & \multicolumn{1}{c}{ May } & June & July & August & March-August \\
\hline \multicolumn{7}{c}{ Sum of precipitation mm } \\
\hline 2009 & 61 & 25 & 66 & 181 & 145 & 50 & 528 \\
2010 & 44 & 51 & 137 & 49 & 124 & 83 & 488 \\
2011 & 26 & 26 & 41 & 64 & 112 & 77 & 346 \\
\hline 2009 & 4 & 11 & 14 & 16 & 20 & 19 & 14 \\
2010 & 3 & 9 & 12 & 18 & 21 & 19 & 14 \\
2011 & 4 & 11 & 14 & 19 & 18 & 19 & 14 \\
\hline
\end{tabular}

Plant material. The study included the following experimental factors: factor I - height of preceding crop stubble: a) low stubble $(10 \mathrm{~cm})$, b) high stubble $(40 \mathrm{~cm})$; factor II - soil tillage systems: a) direct sowing, b) ploughless tillage, c) plough tillage (Table 2); factor III - winter wheat cultivars: a) 'Mewa', b) 'Rapsodia', c) 'Legenda'. The examined cultivars featured the same time of maturity and they reached dough stage after 195197 days starting from the $1^{\text {st }}$ January of analysed year.
In the experiments involving both high and low stubble, the remaining post-harvest residue was shredded into chaff and spread evenly over the field. The surface area of an experimental plot was $15 \mathrm{~m}^{2}$. After harvesting the preceding crop, the plots with high and low stubble were treated with Roundup herbicide in the first ten days of August. In the high stubble treatment, winter wheat was cut at a height of $40 \mathrm{~cm}$, while low stubble was $10 \mathrm{~cm}$ tall.

Table 2. Tillage systems

\begin{tabular}{cl}
\hline Tillage system & \multicolumn{1}{c}{ Cultivation details } \\
\hline \multirow{3}{*}{ Plough tillage } & $\begin{array}{l}\text { Post-harvest cultivation }- \text { cultivator at } 15 \mathrm{~cm}+\text { string roller } \\
\text { Basic land preparation }- \text { ploughing to a depth of } 25 \mathrm{~cm}+\text { harrowing } \\
\text { Pre-plant tillage }- \text { cultivator }+ \text { string roller }\end{array}$ \\
\hline Ploughless tillage & Post-harvest cultivation - cultivator at $15 \mathrm{~cm}+$ string roller \\
& Pre-plant tillage - cultivator + string roller \\
\hline Direct sowing & Direct sowing - Great Plains drill with a double disc drilling unit and a cultivating disc \\
\hline
\end{tabular}


Grain infection. At the milk-dough stage each of the experimental treatments was evaluated according to the frequency of leaves and caryopsis disease. Mycological analyses were performed on the grain of the cultivars harvested at the stage of full maturity. The observations were conducted immediately after the harvest (grain moisture content $<12 \%$ ). In each year of the study, mycological analyses were carried out on 300 wheat grains sampled from each plot of the experiments. The grains were rinsed first with running water and then three more times with distilled water. The material prepared in this way was placed on Petri dishes containing PDA (potato-dextrose agar) medium, previously acidified with citric acid to the $\mathrm{pH}$ level of 5.5. The grains were then incubated in a thermostat chamber at $23^{\circ} \mathrm{C}$ for $7-8$ days. The appearing fungal colonies were transplanted to the PDA slants and identified to the species level with the help of monograph keys (Pitt, Hocking, 2009; Watanabe, 2011). The grain samples from particular experiments showed varied numbers of isolated fungal colonies of Fusarium culmorum. These numbers were subjected to a statistical analysis.

In order to perform mycological analysis, grain samples were collected from each experimental plot, although Fusarium spp. infection is not usually regular on the whole field. Not infected plots (with zero values) always appear in this kind of experiment. Nevertheless, these values cannot be considered as missing data. Therefore, results of this study were subjected to log-linear analysis that enabled analysis of the results, despite the occurrence of occasional zero values in some replications.

Statistical analysis. In biological sciences, the method most frequently used to test the statistical significance of the effect of various factors on the variability of the qualitative trait under study is the log-linear analysis. Under the procedure, all significant deviations of the observed values from the expected ones indicate the existence of a relationship (interaction) between the analysed variables. After a logarithmic transformation of the expected values, the model assumes a linear form that, at its simplest, can be represented by the formula:

$$
\operatorname{Ln}\left(\mathrm{E}_{\mathrm{ij}}\right)=\mathrm{M} .+\lambda_{\mathrm{i}}^{\mathrm{X}}+\lambda_{\mathrm{j}}^{\mathrm{Y}}+\lambda_{\mathrm{ij}}^{\mathrm{XY}}
$$

where $E_{i j}$ are the expected values, $M$. is the general mean based on equal values in each cell, $\lambda_{i} \mathrm{X}-$ the effect of the $i^{\text {th }}$ value of variable $X ; \lambda_{j}{ }^{Y}$ the effect of the $j^{\text {th }}$ value of variable $\mathrm{Y}, \lambda_{\mathrm{ij}} \mathrm{XY}$ - the effect of the interaction of the $\mathrm{i}^{\text {th }}$ value of variable $\mathrm{X}$ and the $\mathrm{j}^{\text {th }}$ value of variable $\mathrm{Y}$.

The log-linear model enables the validation of null hypothesis, which assumes a lack of interaction between two or more of the analysed variables. It also allows, after rejecting all insignificant interactions, an assessment of the effect of particular factors on the variability of the population under study. The interactions between the widespread occurrence of $F$. culmorum on the wheat grain and the wheat cultivars, soil tillage systems, stubble height as well as the duration of the research were demonstrated by means of the log-linear analysis. The analysis of correspondence was applied in order to analyse the variability of the isolated numbers of F. culmorum in relation to the wheat cultivars, soil tillage systems and stubble height. The canonical analysis of correspondence allows an assessment of the structure of relations between the cultivars and the remaining experimental factors under study.

\section{Results}

Regardless of the soil tillage system and the height of the stubble, the analysed wheat grain was infected by the following fungi species: Alternaria alternata (Fr.) Geissler, Botrytis cinerea (Preuss) Woudenberg \& Crous, Epicoccum nigrum Link, Fusarium culmorum (W.G. Smith) Sacc., Penicillium notatum Westling and Sclerotinia sclerotiorum (Lib.) de Bary. Lower infestation was observed among Gibberella avenacea, G. intricans Wollenw., Trichoderma harzianum Rafii, T. viridee Pers. ex S.F. Gray and Trichothecium roseum Link ex Fr.

The statistics provided for the model with the second and third order interactions showed significant values (Table 3). Therefore, the hypothesis regarding the lack of dependence of the F. culmorum populations on the duration of the research, soil tillage systems, stubble heights and wheat cultivars should be rejected

Table 3. Tests of partial and marginal associations and interactions between the investigated factors

\begin{tabular}{|c|c|c|c|c|c|}
\hline Effect & $\begin{array}{l}\text { Degrees of } \\
\text { freedom }\end{array}$ & $\begin{array}{c}\text { Test } \chi^{2} \\
\text { partial } \\
\text { association }\end{array}$ & $\begin{array}{c}\text { Significance } \\
\text { level }(p)\end{array}$ & $\begin{array}{c}\text { Test } \chi^{2} \\
\text { marginal } \\
\text { association }\end{array}$ & $\begin{array}{c}\text { Significance } \\
\text { level }(p)\end{array}$ \\
\hline Years (1) & 2 & 1360.70 & $<0.001$ & 1360.70 & $<0.001$ \\
\hline Stubble height (2) & 1 & 91.75 & $<0.001$ & 91.75 & $<0.001$ \\
\hline Tillage systems (3) & 2 & 220.20 & $<0.001$ & 220.20 & $<0.001$ \\
\hline Cultivars (4) & 2 & 61.64 & $<0.001$ & 61.64 & $<0.001$ \\
\hline $1 \times 2$ & 2 & 326.26 & $<0.001$ & 328.57 & $<0.001$ \\
\hline $1 \times 3$ & 4 & 333.31 & $<0.001$ & 330.76 & $<0.001$ \\
\hline $1 \times 4$ & 4 & 32.89 & $<0,001$ & 33.69 & $<0,001$ \\
\hline $2 \times 3$ & 2 & 45.94 & $<0.001$ & 35.28 & $<0.001$ \\
\hline $2 \times 4$ & 2 & 37.59 & $<0.001$ & 30.29 & $<0.001$ \\
\hline $3 \times 4$ & 4 & 149.91 & $<0.001$ & 137.75 & $<0.001$ \\
\hline $1 \times 2 \times 3$ & 4 & 138.15 & $<0.001$ & 83.44 & $<0.001$ \\
\hline $1 \times 2 \times 4$ & 4 & 82.06 & $<0.001$ & 30.64 & $<0.001$ \\
\hline $1 \times 3 \times 4$ & 8 & 124.26 & $<0.001$ & 176.62 & $<0.001$ \\
\hline $2 \times 3 \times 4$ & 4 & 107.82 & $<0.001$ & 72.11 & $<0.001$ \\
\hline
\end{tabular}


at the level of $p<0.01$. The inclusion of second and third order interactions in the model improved its level of fit, as indicated by the significant values of the $\mathrm{Chi}^{2}$ test. The analysis showed a considerable variability of F. culmorum occurrence in the grain of wheat cultivars during the research. This indicates the importance of the effects of atmospheric conditions on the variability of the occurrence of the fungus under study. It was also found that the occurrence of $F$. culmorum strongly correlated with the height of the preceding crop stubble remaining in the field. The results of the log-linear analysis show a strong relationship between tillage systems and stubble height. The varied height of the preceding crop stubble enhanced the impact of the soil tillage systems under study on the occurrence of $F$. culmorum on wheat grain obtained from the cultivars which were the subject of the research.

Plough tillage contributed to the reduction in the number of $F$. culmorum, while direct sowing seemed conducive to its development (Table 4). The cultivars displayed varied resistance to grain infection with F. culmorum. In high stubble conditions, the cv. 'Legenda' showed increased resistance to the $F$. culmorum fungus. The cv. 'Rapsodia' proved susceptible to the fungus.

Table 4. The number of Fusarium culmorum isolates in wheat grain in relation to the cultivar and cultivation methods (sum for 2009-2011)

\begin{tabular}{|c|c|c|c|c|}
\hline \multirow{2}{*}{ Tillage systems } & \multicolumn{3}{|c|}{ Number of $F$. culmorum isolates } & \multirow{2}{*}{ Mean } \\
\hline & 'Legenda' & 'Rapsodia' & 'Mewa' & \\
\hline \multicolumn{5}{|c|}{ High stubble $(40 \mathrm{~cm})$ of preceding crop - examined cultivars } \\
\hline Direct sowing & 207 & 229 & 263 & 233.0 \\
\hline Simplified tillage & 123 & 99 & 107 & 109.7 \\
\hline Plough tillage & 68 & 208 & 119 & 131.7 \\
\hline LSD & 54.8 & 107.2 & 110.4 & 87.4 \\
\hline Means & 132.7 & 178.7 & 163.0 & 158.1 \\
\hline LSD for cultivars & & \multicolumn{2}{|c|}{ LSD Ior cuitivars } & \\
\hline \multicolumn{5}{|c|}{ Low stubble $(10 \mathrm{~cm})$ of preceding crop - examined cultivars } \\
\hline Direct sowing & 248 & 299 & 305 & 284.0 \\
\hline Simplified tillage & 225 & 221 & 197 & 214.3 \\
\hline Plough tillage & 181 & 173 & 134 & 162.7 \\
\hline LSD & 34.7 & 82.7 & 101.5 & 114.2 \\
\hline Means & 218.0 & 231.0 & 212.0 & 220.3 \\
\hline LSD for cultivars & \multicolumn{2}{|c|}{ ns } & & \\
\hline
\end{tabular}

LSD - lowest significant difference, ns - no significant difference

Smaller differences in the number of F. culmorum isolates occurred in low stubble conditions. The data shown in Tables 3 and 5 indicate that in the years 2009 and 2010, during which the vegetative period was characterized by high levels of precipitation, the incidence of the fungal infection was much higher than in 2011, when the precipitation levels were much lower. Low rainfall appeared to significantly reduce the population of F. culmorum. In the years 2011 and 2010, low proceeding crop stubble caused an increase in the number of $F$. culmorum. In 2009, however, the reverse was observed.

Table 5. The number of Fusarium culmorum isolates in wheat grain in relation to stubble height and year of study

\begin{tabular}{ccccc}
\hline \multirow{2}{*}{$\begin{array}{c}\text { Stubble } \\
\text { height }\end{array}$} & \multicolumn{3}{c}{ Number of isolates } & \multirow{2}{*}{ Total } \\
\cline { 2 - 4 } & 2009 & 2010 & 2011 & \\
\hline High & 293 & 968 & 162 & 1423 \\
Low & 997 & 885 & 101 & 1983 \\
Total & 1290 & 1853 & 263 & - \\
\hline
\end{tabular}

The aim of the second part of the study was to analyse the dependence of the $F$. culmorum fungus on the following experimental factors: duration, soil tillage systems, stubble height and cultivars. In order to accomplish this, the analysis of correspondence was applied. The graphs representing the cultivars' response to the analysed experimental factors are presented in a two-dimensional space in order to retain the complete information on the varied effects of the experimental factors on the population of $F$. culmorum (Fig.). By analysing the distribution of particular wheat cultivars in a two-dimensional space we can observe that each of the cultivars forms a separate single-element homogeneous group differing considerably with respect to the occurrence of F. culmorum, which, in turn, correlates with the duration of the research, tillage systems and height of stubble. This is indicated by the significant distances between the cultivars in the analysed biplot diagram. Drawing on the length of the vector, it may be concluded that the cultivars exhibited the greatest variability of infection by F. culmorum under the following conditions: high preceding crop stubble and plough tillage. The angles between the vectors indicate that in the case of 


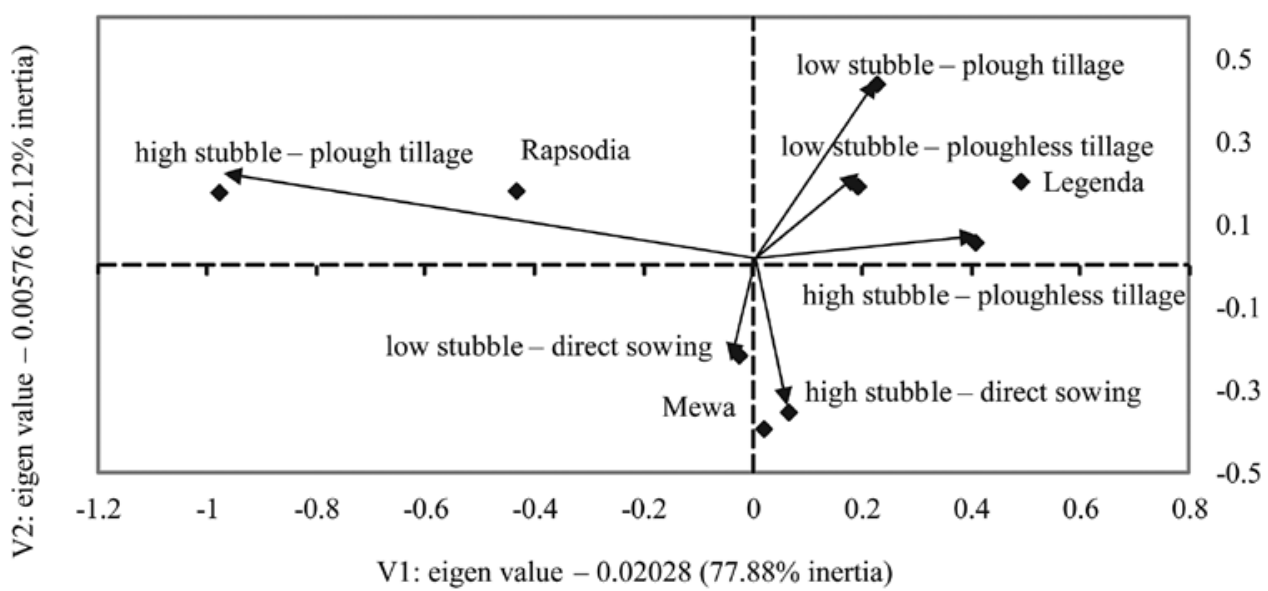

Figure. Biplot - the variability (V1, V2) of the susceptibility of wheat cultivars to infection by Fusarium culmorum in relation to the height of the preceding crop stubble, tillage systems and vegetative season

ploughless tillage or zero tillage the height of the stubble did not cause any considerable changes in the occurrence of F. culmorum. Conversely, the orthogonal projections of points representing the cultivars onto the vectors of variables show increased infection of cv. 'Rapsodia' with $F$. culmorum in plough tillage and high stubble systems. Direct sowing, regardless of stubble height, was conducive to the development of the fungus on the grain of cv. 'Mewa', while in ploughless tillage system the greatest number of $F$. culmorum was observed on the grain of cv. 'Legenda'.

\section{Discussion}

The results of the study indicate that in the years during which the vegetative season was characterised by high levels of rainfall and higher air temperatures in July, the occurrence of $F$. culmorum was higher than in 2011. Bateman et al. (2007) emphasise the significant impact of rainfall on the degree of wheat infection with the $F$. culmorum fungus. Rain droplets carrying the macroconidia of $F$. culmorum contribute to the infection of the plant's stem base and, subsequently, the head. The most important factors determining the degree of wheat ear infection are: temperature, air humidity, cultivar resistance and availability of water (Brennan et al., 2005; Popovski, Celar, 2013). Temperatures exceeding $25^{\circ} \mathrm{C}$ and high air humidity lasting 24 hours create the most favourable conditions for the infection of plants with Fusarium spp. The log-linear analysis confirmed a considerable variation of the susceptibility of the wheat cultivars to infection with the $F$. culmorum fungus. Fungicides used against fusarium head blight showed limited effectiveness (Pląskowska, ChrzanowskaDrożdż, 2009; Blandino et al., 2010; Gilbert, Haber, 2013). Therefore, the selection of cultivars characterised by an increased resistance to the most frequently occurring pathogenic fungi is the primary yield-forming factor. Studies conducted in Canada demonstrated a varied response of the fungi to soil tillage systems (Fernandez et al., 2008).
Winter oilseed rape preceding crop and direct sowing were responsible for a greater rate of infection with Gibberella avenacea observed on wheat ears compared to plough tillage, whereas the reverse was demonstrated in the case of $F$. graminearum (Fernandez et al., 2008). Varied responses of $G$. avenacea, $G$. zeae and $F$. culmorum to ploughless tillage systems were observed in Germany and Poland (Guo et al., 2010; Weber, Kita, 2010). These studies indicate that a oneyear break in the cultivation of cereals increases the occurrence of F. culmorum in plough tillage systems, to the point that it becomes greater than when direct sowing is applied. Ploughed over to the depth of $20-25 \mathrm{~cm}$, the thick-walled chlamydospores are not destroyed, as opposed to the ascospores of G. zeae and G. avenacea (conservation effect of plough tillage). The experiment showed that annual tillage following a preceding winter wheat crop did not cause an increase in the number of $F$. culmorum isolates. The small number of isolates of other species of fungi may be due to low rainfall in Lower Silesia. F. culmorum can develop and sporulate even when the water potential of soil is low. Studies conducted in Luxembourg have shown that in each year when there was a decrease in precipitation during the growing season, $90 \%$ of sick ears were infected by F. culmorum, and only $10 \%$ by F. graminearum (Giraud et al., 2010).

The subsequent ploughing brings the spores of the fungus back to the surface of the soil, where cereal cultivation creates optimum conditions for their growth and development. On the other hand, surface (ploughless) tillage, characterised by greater biological activity of the soil, may largely inhibit the growth of that fungus species. Temperature changes during winter also contribute to the destruction of the spore forms of F. culmorum. The study shows that the increased occurrence of $F$. culmorum in the case of direct sowing, as opposed to plough tillage, results from the fact that preceding winter wheat crop was applied before the planting of winter wheat cultivars. 
On the other hand, in the crop rotation pattern winter wheat - preceding winter rape crop - winter wheat, a higher occurrence of $F$. culmorum is attributable to its preserving effect (Weber, Kita, 2010). However, the study in Lithuania showed no significant influence of tillage system on wheat infection by Fusarium fungi (Suproniene et al., 2012). The discrepancy in results of the investigated issue can be due to variable species composition of fungi population.

The development of Fusarium spp. can be successfully suppressed by antagonistic rhizospheric microorganisms, species of fungi belonging to the Trichoderma genus as well as Pseudomonas and gram-positive Arthrobacter bacteria (Scherm et al., 2013). Under laboratory conditions, the addition of two microbiological strains $P$. fluorescens MKB 100 and Pseudomonas spp. MKB 158 and 249, helped in containing head blight in seedlings caused by F. culmorum (Khan et al., 2006). In the cases of wheat wheat rotation, phytosanitary mechanism is triggered off by all kinds of catch crops, especially fodder plants such as oilseed rape, white mustard and oilseed radish. Catch crops consisting of winter vetch, white clover or hybrid alfalfa may significantly reduce the incidence of Fusarium spp. in crops (Moszczyńska, Pląskowska, 2005). However, sowing wheat after a preceding crop of corn may induce considerable infection of grain by mycotoxins (DON, NIV and ZEA) of Fusarium fungi (Vogelgsang et al., 2011).

\section{Conclusions}

1. Various environmental conditions, especially rainfall, in the highest degree contributed to the diversity of the number of Fusarium culmorum in winter wheat grain in particular years of the experiment.

2. The number of F. culmorum isolates was greater under no-tillage conditions as compared to conventional tillage system.

3. Smaller infection of winter wheat grain by F. culmorum was observed at high stubble for each tillage system.

4. Under high stubble conditions, winter wheat cultivars featured diversified resistance to F. culmorum infection depending on tillage system. In contrast, low stubble did not differentiate wheat resistance.

5 . The results of this research proved interactions between cultivar, stubble height and tillage system. The significance of these interactions points out diversified response of the cultivars with respect to their resistance to Fusarium fungi depending on stubble height and tillage system.

Received 19082015 Accepted 19112015

\section{References}

Bateman G. L., Gutteridge R. J., Gherbawy Y., Thomsett M. A., Nicholson P. 2007. Infection of stem bases and grains of winter wheat by Fusarium culmorum and F. graminearum and impact of tillage methods and maize-stalk residues. Plant Pathology, 56 (4): 604-615

http://dx.doi.org/10.1111/j.1365-3059.2007.01577.x

Blandino M., Pilati A., Reyneri A., Scudellari D. 2010. Effect of the density of crop residue on Fusarium head blight and deoxynivalenol contamination of common wheat grains. Cereal Research Communications, 38 (4): 550-559 http://dx.doi.org/10.1556/CRC.38.2010.4.12

Brennan J. M., Egan D., Cooke B. M., Doohan F. M. 2005. Effect of temperature on head blight of wheat caused by Fusarium culmorum and F. graminearum. Plant Pathology, 54 (2): 156-160 http://dx.doi.org/10.1111/j.1365-3059.2005.01157.x

Fernandez M. R., Huber D., Basnyat P., Zentner R. P. 2008. The impact of agronomic practices on Fusarium and other fungi in cereal and noncereal crop residues on the Canadian Prairies. Soil and Tillage Research, 100 (1-2): 60-71 http://dx.doi.org/10.1016/j.still.2008.04.008

Gilbert J., Haber S. 2013. Overview of some recent research developments in fusarium head blight of wheat. Canadian Journal of Plant Pathology, 35 (2): 149-174 http://dx.doi.org/10.1080/07060661.2013.772921

Giraud F., Pasquali M., El Jarroudi M., Vrancken C., Brochot C., Cocco E., Hoffmann L., Delfosse P., Bohn T. 2010. Fusarium head blight and associated mycotoxin occurrence in winter wheat in Luxembourg in 2007/2008. Food Additives and Contaminants, 27 (6): 825-835 http://dx.doi.org/10.1080/19440040903567232

Guo X. W., Fernando W. G. D., Bullock P., Sapirstein H. 2010. Quantifying cropping practices in relation to inoculum levels of Fusarium graminearum on crop stubble. Plant Pathology, 59 (6): 1107-1113 http://dx.doi.org/10.1111/j.1365-3059.2010.02353.x

Häberle J., Schmolke M., Zimmermann G., Miedaner T., Korzun V., Ebmeyer E. 2007. Effects of two major Fusarium head blight resistance QTL verified in a winter wheat backcross population. Crop Science, 47 (5): 1823-1831 http://dx.doi.org/10.2135/cropsci2006.12.0800

Infantino A., Santori A., Shah D. A. 2012. Community structure of the Fusarium complex on wheat seed in Italy. European Journal of Plant Pathology, 132 (4): 499-510 http://dx.doi.org/10.1007/s10658-011-9892-1

Kammoun L. G., Gargouri S., Barreau C., Richard-forget F., Hajlaoui M. R. 2010. Trichothecene chemotypes of Fusarium culmorum infecting wheat in Tunisia. International Journal of Food Microbiology, 140 (1): 84-89 http://dx.doi.org/10.1016/j.ijfoodmicro.2010.01.040

Khan M. R., Fischer S., Egan D., Doohan F. M. 2006. Biological control of Fusarium seedling head blight disease of wheat and barley. Phytopathology, 96 (4): 386-394 http://dx.doi.org/10.1094/PHYTO-96-0386 
Klix M. B., Beyer M., Verreet J. A. 2008. Effects of cultivar, agronomic practices, geographic location, and meteorological conditions on the composition of selected Fusarium species occurring on wheat heads. Canadian Journal of Plant Pathology, 30 (1): 46-57 http://dx.doi.org/10.1080/07060660809507495

Lenc L., Wyczling D., Sadowski C. 2009. Occurrence of Fusarium genus in winter wheat grains depending on preceding crop, cultivar and fungicides. Ochrona Środowska i Zasobów. Naturalnych, 41: 563-571 (in Polish)

Maiorano A., Blandino M., Reyneri A., Vanara F. 2008. Effects of maize residues on Fusarium spp. infection and deoxynivalenol (DON) contamination of wheat grain. Crop Protection, 27 (2): 182-188 http://dx.doi.org/10.1016/j.cropro.2007.05.004

Moszczyńska E., Pląskowska E. 2005. Assessment of heath of winter wheat cultivated traditionally applying direct sowing with and without white clover. Acta Agrobotanica, 58 (2): 277-286 (in Polish) http://dx.doi.org/10.5586/aa.2005.055

Pitt J. I., Hocking A. D. 2009. Fungi and food spoilage. New York, USA, $421 \mathrm{p}$. http://dx.doi.org/10.1007/978-0-387-92207-2

Pląskowska E., Chrzanowska-Drożdż B. 2009. The health of winter durum wheat grain in relation to fungicide treatment. Phytopathologia, 54: 23-32

Popovski S., Celar F. A. 2013. The impact of environmental factors on infection of cereals with Fusarium species and mycotoxin production - a review. Acta Agriculturae Slovenica, 101 (1): 105-116 http://dx.doi.org/10.2478/acas-2013-0012

Scherm B., Balmas V., Spanu F., Pani G., Delogu G., Pasquali M., Migheli Q. 2013. Fusarium culmorum: causal agent of foot and root rot and head blight on wheat. Molecular Plant Pathology, 14 (4): 323-341 http://dx.doi.org/10.1111/mpp.12011

Summerell B., Laurence M. H., Liew E. C. Y., Leslie J. F. 2010. Biogeography and phylogeography of Fusarium: a review. Fungal Diversity, 44 (1): 3-13 http://dx.doi.org/10.1007/s13225-010-0060-2

Supronienė S., Mankevičienė A., Kadžienė G., Kačergius A., Feiza V., Feizienė D., Semaškienė R., Dabkevičius Z., Tamošiūnas K. 2012. The impact of tillage and fertilization on Fusarium infection and mycotoxin production in wheat grains. Zemdirbyste-Agriculture, 99 (3): 265-272

Vogelgsang S., Hecker A., Musa T., Dorn B., Forrer H. R. 2011. On-farm experiments over 5 years in a grain maize/ winter wheat rotation: effect of maize residue treatments on Fusarium graminearum infection and deoxynivalenol contamination in wheat. Mycotoxin Research, 27 (2): 81-96 http://dx.doi.org/10.1007/s12550-010-0079-y

Wagacha J. M., Muthomi J. W. 2007. Fusarium culmorum: infection process, mechanisms of mycotoxin production and their role in pathogenesis in wheat. Crop Protection, 26 (7): $877-88$

http://dx.doi.org/10.1016/j.cropro.2006.09.003
Watanabe T. 2011. Pictorial atlas of soil and seed fungi: morphologies of fungi and species key, $404 \mathrm{p}$.

Weber R., Kita W. 2010. The effects of tillage systems and preceding crop types on the frequency of the incidence of Fusarium culmorum and Fusarium avenaceum on culm bases of some winter wheat cultivars. Acta Agrobotanica, 63 (1): $121-128$ http://dx.doi.org/10.5586/aa.2010.014

Xu X.-M., Nicholson P. 2009. Community ecology of fungal pathogens causing wheat head blight. Annual Review of Phytopathology, 47: 83-103

http://dx.doi.org/10.1146/annurev-phyto-080508-081737

Xu X.-M., Nicholson P., Thomsett M. A., Simpson D., Cooke B. M., Doohan F. M., Brennan J., Monaghan S., Moretti A., Mule G., Hornok L., Beki E., Tatnell J., RitieniA., Edwards S. G. 2008. Relationship between the fungal complex causing Fusarium head blight of wheat and environmental conditions. Phytopathology, 98 (1): 69-78 http://dx.doi.org/10.1094/PHYTO-98-1-0069

Yli-Mattila T. 2010. Invited review ecology and evolution of toxigenic fusarium species in cereals in northern Europe and Asia. Journal of Plant Pathology, 92 (1): 7-18 
ISSN 1392-3196 / e-ISSN 2335-8947

Zemdirbyste-Agriculture, vol. 103, No. 1 (2016), p. 45-52

DOI 10.13080/z-a.2016.103.006

\title{
Fusarium culmorum paplitimo ant žieminių kviečių grūdụ kitimas priklausomai nuo klimato sąlygų ir auginimo būdụ
}

\author{
R. Weber ${ }^{1}$, W. Kita², W. Pusz², R. Kieloch ${ }^{1}$ \\ ${ }^{1}$ Lenkijos valstybinis mokslinių tyrimų institutas Dirvožemio ir augalininkystès institutas \\ ${ }^{2}$ Vroclavo aplinkos ir gyvybės mokslų universitetas, Lenkija
}

\begin{abstract}
Santrauka
Kviečių grūdus kolonizuoja įvairūs saprofitiniai ir patogeniniai grybai. Mikotoksigeniškų rūšių, pavyzdžiui, Fusarium spp., paplitimas kelia grèsmę grūdų, skirtų žmonèms ir gyvuliams, saugumui. Grūdų užterštumas grybais priklauso nuo ịvairių aplinkos ir genetinių veiksnių. Tyrimo tikslas - išanalizuoti Fusarium culmorum grybų paplitimo ant kviečių grūdų kitimą, priklausomai nuo bandymo metų aplinkos sąlygų, priešsėlio ražienų aukščio, dirvožemio dirbimo būdo ir veislès. Tyrimas atliktas 2009-2011 m. Dirvožemio ir augalininkystès instituto, esančio Žemutinès Silezijos regione, bandymų ūkyje. Priešsèlis buvo žieminiai kviečiai. Bandymą sudarè šie veiksniai: I - priešsėlio ražienų aukštis: a) žema ražiena, b) aukšta ražiena; II - žemės dirbimo būdas: a) tiesioginè sẻja, b) neariminis dirbimas, c) ariminis dirbimas; III - žieminių kviečių veislès: a) 'Mewa', b) 'Rapsodia', c) 'Legenda'. Grūdų mikologinès analizès buvo atliktos juos nuėmus pilnos brandos tarpsniu. Nustatyta, kad taikant nearimini dirbimą grybų paplitimas tirtuose grūduose buvo didesnis nei dirvožemị ariant. Grūdų užsikrètimo F. culmorum grybu lygis buvo mažesnis aukštų ražienų variante taikant visus žemės dirbimo būdus. Kviečių veislių atsparumas grūdų užkrèstumui F. culmorum grybais ịvairavo priklausomai nuo žemès dirbimo būdo.
\end{abstract}

Reikšminiai žodžiai: aplinka, Fusarium culmorum, ražienų aukštis, žemės dirbimo sistema.

Please use the following format when citing the article:

Weber R., Kita W., Pusz W., Kieloch R. 2016. The variability of the occurrence of Fusarium culmorum in winter wheat grain in relation to climatic conditions and cultivation methods. Zemdirbyste-Agriculture, 103 (1): 45-52 DOI 10.13080/z-a.2016.103.006 